\title{
En datters opplevelse når mor rammes av demens
}

\section{Helsepersonell som samhandler med pasienter og pårørende, kan lære av pårørendes erfaringer når en nærstående rammes av demens.}

\section{FORFATTERE}

Betty-Ann Solvoll

Førsteamanuensis og postdoktor

Nord universitet

\section{SAMMENDRAG}

Bakgrunn: Demenssykdom rammer ikke bare den som blir syk, men også den nære familien. Kunnskap om deres erfaringer har betydning for helsepersonell som samhandler med pasienter og pårørende.

Hensikt: Å utforske pårørendes erfaringer når nærstående rammes av sykdom og har kort tid igjen å leve. Erfaringene hentes fra Marie Petersons dokumentarroman Du tror du vet alt. Utgangspunktet er spørsmålet: «Hvordan oppleves det å være datter når mor rammes av demens?»

Metode: Essay er brukt som kritisk utforskende metode.

Resultat: Fortellingen gir innsikt i hvordan det er å være pårørende når en nærstående blir syk, hjelpetrengende og nærmer seg døden. Når en nærstående rammes av sykdom, vekkes trangen til å forstå hva som er i ferd med å skje. Det er mye å undre seg over i takt med sykdomsutviklingen, og enda mer når døden nærmer seg. Det kan synes paradoksalt at Marie prøver å "finne fram til sin mor», uten noen gang å nå fram. Det er også motsetningsfylt at mens Marie søker å forstå, skal hun samtidig gi slipp. Hvilken hjelp er det mulig å gi en pårørende som strever med å begripe og på samme tid skal gi slipp?

Konklusjon: Boken viser innlevende det relasjonelle samspillet mellom en syk mor og hennes datter fram mot morens $d \varnothing d$. Datterens deltakelse i morens lidelser og hennes strev med å gjenfinne fotfeste gjør oss klokere, og vi forstår hva som står på spill i relasjonen. Slik er boken en unik kilde til å forstå både mor og datter. Den inspirerer til samtaler om relasjoner, livet og døden - og behovet for sykepleiefaglig støtte.

Hensikten med dette essayet er å utforske pårørendes erfaringer når nærstående rammes av demens. Utgangspunktet er en datters erfaring med at moren utvikler demens. Temaet utforskes ved å analysere Marie Petersons dokumentarroman Du tror du vet alt (1). Essayet er en refleksjon over pårørendes erfaringer og tar utgangspunkt i spørsmålet: «Hvordan oppleves det å være datter når mor rammes av en demenssykdom?» 


\section{TRANG TIL Å FORSTÅ}

Marie opplever en rekke hendelser med mor som vekker en trang til å forstå. Mor vil for eksempel i banken, og Marie skal følge med. Språkbristen gjør at ikke alt mor sier, uten videre er lett å forstå.

«Jeg må ha for hendene ...»

«Mener du hansker? ... Denne skal være på høyre hånd og denne på venstre.»

Den lettere belæringen irriterer mor: «Du tror du vet alt», hveser hun $(1, \mathrm{s.} 7)$.

Boken åpner med denne replikkvekslingen. Vi øyner frustrasjon og underliggende irritasjon. Sterke viljer og heftige temperamenter braker sammen. Maries mor er pensjonert skolebibliotekar. Hun har alltid vært og er fortsatt en sterk og selvstendig kvinne. Hun har hatt et tøft liv, men har lagt vekt på å klare seg selv. Nå blir hun stadig mer glemsk.

Som barn i et skilsmissehjem har Marie ikke vokst opp hos sin mor. Mor forlot hjemmet da Marie var to og søsteren bare en liten baby: «Hun er moren min, jeg er datteren hennes, men vi har aldri delt hverdagen.» $(1$, s. 124) Nå legger datteren betydelig innsats i å forstå og hjelpe den skrantende og etter hvert hjelpetrengende moren. Mor selv insisterer på å klare seg alene og fraber seg inngripen.

\section{NÅR LIVET SNUR}

Livet snus på hodet når mor blir syk. Marie får en telefon fra sin søster: «[M]amma kan ikke klokken.» Opplysningen virker helt surrealistisk. «Det kan hun vel», svarer Marie (1, s. 19). Det skal vise seg at mors kognitive grep om livet, også om klokken, er i ferd med å glippe. Hukommelsen svikter, og atferden endres. Endringene kaster Marie ut i usikkerhet og forvirring.

Det gjør vondt å se mor lete etter ordene. Hun kommer ikke til poenget og blir pinlig berørt av det. Marie prøver å finne et system i språkforvitringen. Abstraksjoner blir vanskelige for mor. «Det er logisk», tenker Marie, «men hvorfor forsvinner verbene før substantivene?» Språket demonteres merkbart.

I et fors $\varnothing \mathrm{k}$ på å forstå mor går Marie gjennom gamle brev hun har fått fra henne. Hun sammenlikner brev fra før mor ble syk med dem hun får etterpå. Marie ser på håndskriften, leter etter «tonen» i brevene. De første er upersonlige. Hun får et saksorientert brev i tolvårsalderen, som om mor skrev til en jevnaldrende venn. I de siste brevene er hengivenheten en helt annen: «[S]tor klem, håper du kommer snart, kyss, kyss, kyss.» (1, s. 17). I voksen alder kaller mor henne «sin lille dununge» (1, s. 97). Mor og datter har alltid vært i utakt.

\section{PRøVER Å FORSTÅ SEG SELV FOR Å FORSTÅ MOR}

I begynnelsen er besøkene til mor diktert av håndfaste behov. Marie lytter til henne i et forsøk på å forstå en gåtefull og brutal sykdom. De minnene mor har, må hun ta vare på. Etter hvert merker Marie at hun selv skifter spor. Det handler mer og mer om hennes eget liv enn morens. Det slår meg at første del av boken formidler Maries streben etter å forstå mor. I siste del handler boken om å forstå seg selv. Og imens går mor i stykker ... (1, s. 51).

\section{«Mors sykdom skaper en trang i Marie til å forstå hva som skjer i mor og hvordan sykdommen endrer atferd og språk.»}


Mors sykdom skaper en trang i Marie til å forstå hva som skjer i mor og hvordan sykdommen endrer atferd og språk. Besøkene hos mor vekker også en lengsel etter å forstå hvem mor var. Og i forlengelsen av det en lengsel etter å forstå sin egen barndom. Samtalene, tiden med å bla i fotoalbum og gjennomgå tidligere brev blir oppdagelser og innsikter som gjør det mulig for Marie å forstå tiden som barn på nye måter samt nyansere fortiden og mors rolle i den.

Sykdommen Alzheimer setter ikke bare søkelyset på mor og den hun var. Marie blir også konfrontert med seg selv og sine relasjoner til mor - før og nå. Til slutt forsoner Marie seg med tingenes tilstand - at hun ikke akkurat lyktes med å forsone seg med sin mor, «men det viktigste var at vi prøvde» (1, s. 157). Maries fortelling viser noe allment i det å stå overfor en skremmende sykdom der døden er en uunngåelig utgang. Trangen til å forstå hva som skjer, og behovet for å oppsummere eget liv når foreldrene er i ferd med å avslutte sine liv, er noe alle pårørende kan oppleve.

\section{FORSTÅELSE PÅ ULIKE NIVÅER}

Med den dødelige sykdommen Alzheimer kastes Marie inn i uro. «Fører til døden, fører til døden», gjentar Marie, men forstår fortsatt ikke: «Hvordan kan man dø av det? Glemmer man å leve?» (1, s. 21). Å miste språk og evne til å tenke er truende, både for den som rammes og for pårørende.

Klokketesten er enkel, men demonstrerer alvorlig kognitiv svikt. Sirkelen mor tegner, henger ikke sammen. Etter mye tvil markerer hun urviserne på elleve når hun skal vise at klokken er tre. For språkentusiasten blir testsituasjonen høyst pinlig. For Marie er det sjokkerende. Testen blir et tegn på sykdom og samtidig en symbolsk erklæring: Nå begynner nedtellingen. Mors dager er talte. Tankene blir påtrengende. Marie koker kaffe og tenker: «demens». Hun vasker opp og tankene gnager: «Alzheimer er dødelig ... legen sa femten år ...» (1, s. 21).

Psykiateren Lars Sjöstrand (2) skriver at mennesker forstår på ulike nivåer - konkret så vel som eksistensielt. Forklaringer om celleforandringer som medfører celled $\varnothing \mathrm{d}$ i hjernen er ett nivå, men det berører ikke spørsmål knyttet til død og eksistens. Sjöstrand kaller det «dødens fenomenologi». Marie konfronteres med mors forestående død. Mors eksistens er ved en avslutning.

Eksistens kjennetegner det bevisste mennesket og innebærer «å stå opp eller å overskride seg selv» (2, s. 22). Det er nettopp det Marie gjør. For henne innebærer tanken om morens $d \emptyset d$ en eksistensiell utfordring. Marie har et genuint $\emptyset n s k e$ om å finne fram til sin mamma. Nå er tiden knapp. Marie smaker på ordet «mamma». Mor er ikke mamma, har aldri vært det. Når Marie tenker på mor, tenker hun på «Siv». Iblant tenker hun bare på latteren hennes. Hun tenker på en som ikke brydde seg om å verge henne da hun trengte det som mest - og som i sin tur avviste datterens spørsmål ved selv å begynne å gråte.

\section{SøKER ETTER FELLES ERFARINGER}

I mors sykdomsfase besøker Marie henne ofte. Timer tilbringes med å kikke på gamle bilder. Felles erfaringer som ingen av dem husker klart. Mor som svinger seg foran et speil og skal ut. Hendene til mor, alltid beskjeftiget, sterke og ru. Marie husker ikke en eneste kjærtegnende berøring. Å kikke på bilder har minst to funksjoner; det gir mor og datter noe å være sammen om, og det vekker minner.

Mennesket integrerer alltid tiden i sine opplevelser. Slik lever det ikke bare i nuet, i det aktuelle, men søker å binde fortid i nåtid med tanke på framtid (2). Samtidig gjør bildene 


\section{«Mors sykdom gjør det tydeligere for Marie at livet har sin grense, og det vekker behovet for en oppsummering.»}

Mors sykdom gjør det tydeligere for Marie at livet har sin grense, og det vekker behovet for en oppsummering. Nedbrytningene i kroppen til moren og den forestående $d \varnothing d$ vitner om en siste sjanse til å finne fram til henne. Eller snarere - en siste sjanse for Marie til å oppleve at mor ønsker å finne fram til sin eldste datter. «Det var et latterlig ønske», innrømmer hun $(1$, s. 147). Like fullt fors $\varnothing$ ker hun. Bilder og gamle brev blir hjelpemidler i oppsummeringen. Kalkylen kommer dårlig ut for Marie. Mor er som hun alltid var: selvopptatt og selvsentrert.

\section{DØDEN OPPSUMMERER LIVET}

Til sist må Marie ta sin mor til sykehjem med tvang. Mor er forkommen av mangel på stell etter lengre tid alene i egen leilighet. Det utspinner seg hjerterå scener. Både mor og datter er temperamentsfulle. De blir stående og skrike til hverandre. Mor er sterk og sint, Marie fortvilet. Det er lite i situasjonen som minner om et mor-datterforhold der de nærmer seg hverandre. Eller er det nettopp det som skjer? Mor freser og skriker. Marie tar igjen (1, s. 78).

Maries streben etter å forstå foregår på flere plan. Den foregår på det konkrete planet - på sykdommens utvikling, på mors atferd og behov. Bestrebelser på å forstå foregår også på det abstrakte planet - på livet som var, som snart er over, og på døden. På mor og på seg selv. Døden er et sluttmål for livsløpet og blir et endemål som bidrar til å avgrense og definere livet (2). Forestillingen om mors forestående $d ø d$ oppsummerer livet til en helhet, ikke bare mors liv, men også Maries liv. Trangen til å forstå er gjennomgripende for Marie.

\section{OM Å GI SLIPP}

Det ligger en sår undertone av søken i boken. Marie ønsker sterkt å finne fram til sin mor, og hun bærer på en dyp trang til at mor skal få lyst til å finne henne: «Det var derfor jeg besøkte henne så ofte. Jeg håpet at hun skulle ha lyst til å bli kjent med meg. Jeg håpet at hun skulle bli, ikke en mamma, for det var for sent, men noen som var litt mer normal.» $(1$, s. 147)

\section{«Marie ønsker sterkt å finne fram til sin mor, og hun bærer på en dyp trang til at mor skal få lyst til å finne henne.»}

Så har Marie en avgjørende opplevelse. Hun ser plutselig grensene som hun selv har satt opp i relasjonen til mor. Disse overgir hun nå. I et skjellsettende øyeblikk skjer det: «... og det tok ikke mer tid enn å skifte hånd på en handlepose ... Den grensen hadde vært stabil i mange år, med meg selv som den strengeste grensevakt.» (1, s. 146). Det går plutselig opp for Marie at hun har levd i forsvar. Hun får et nytt blikk på mor: «Hun er så liten, så mager, stort sett bare en gammel dame, helt ufarlig.» $(1$, s. 152) Nå makter Marie til og med å ta imot komplimenter: «Jeg liker deg veldig godt, sier mor. Det har mor aldri sagt før.» (1, s. 159) 
bilder: « ... som om jeg blir fylt med vann. Når det når hjertet forvandles det plutselig til en stein som trenger seg inn i blodomløpet ... og sirkulerer ... og hver gang den passerer hjertet kommer smerten tilbake» (1, s. 155). En altoppslukende sorg, som kjennes i ethvert åndedrag: «... verst når jeg puster inn. Nei, det er verst når jeg puster ut.» (1, s. 155)

Sorgen synes å hjelpe til med å slippe taket. Den orienterer om at tiden er inne. Marie «slipper taket» ved å se mor for seg: Mor sitter i en båt, halvveis bortvendt og ser utover vannet. Båten ligger med baugen i sanden. Marie sitter på huk og holder i rekka på båten med begge hender. Vil ikke slippe, men må. «Mor ser så ensom ut! Og det er som om hendene vet hva de skal gjøre. De slipper taket i båten. Og mens hun glir ut, forstår jeg at jeg kom fram. ... Strengt tatt var forsøket vårt helt mislykket. Men det viktigste er at vi prøvde.» $(1$, s. 157)

\section{OPPGJøR MED BARNDOMMEN}

En barndom kan være en lang «dom» å sone. Langt opp i voksen alder bærer Marie på en lengsel etter mamma. Barndommens mor var sjelden til stede for henne. Morens valg og handlinger blir krenkende for Marie. Handlinger innebærer alltid en risiko for forseelser, hevder Hannah Arendt (3). Det ligger i handlingens karakter at den kan forulempe andre, ofte uten at den som handler, er klar over det (3, s. 242).

En måte å forstå Marie på, er at hun i voksen alder tar et oppgjør med forsømmelser fra barndommen. Bildene hun og mor ser på, viser at hun ikke var til stede i mors liv. Brevene signaliserer mors upersonlige og manglende engasjement i barneårene. Fra et «Arendtsk» synspunkt kan man forstå at datteren ble forulempet, uten at mor selv visste eller skjønte at hun hadde krenket henne. Som leser kan man undre seg over hvordan det er mulig for en mor å svikte sitt barn så grundig, uten «å vite hva man gjør».

Handlinger kjennetegnes ved å være ugjenkallelige (3, s. 242). Selv om mor hadde angret, ville tidligere handlinger ikke kunne omgjøres. Marie må leve med følgene av sin mors handlinger. Er mennesker dømt til å leve under byrdene av tidligere fors $\varnothing$ mmelser? «Nei», mener Arendt, «det forløsende middelet mot handlingers krenkelser og det ugjenkallelige i det, ligger i evnen til å tilgi» (3, s. 243). Det som en gang er gjort, kan ikke reverseres.

Det er imidlertid mulig å bli løst fra følgene av krenkende handlinger ved å tilgi. Tilgivelsen gir en ny begynnelse. Det er ikke handlingen man tilgir, men personen. Anklageren sier «du krenket meg» (3, s. 243). Spørsmålet om tilgivelse gjelder primært for handlinger som ikke er ment krenkende, mener Arendt. Med handlinger som har onde hensikter, der «mennesket er klar over det onde på forhånd», forholder det seg annerledes (3, s. 246).

\section{TILGIVELSENS BETYDNING}

Tilgivelse er en relasjon, hevder Arendt, og angir dermed at det er noe som foregår mellom mennesker ( 3 , s. 248). Noe av det sterkeste boken beskriver, er nettopp når Marie skriver om den nye relasjonen som oppstår med erfaringen av den skjellsettende hendelsen. Brutte relasjoner gjenopprettes. Evnen til å tilgi har betydning for menneskers psykiske helse $(4,5)$.

Det engelske ordet «reconciliation» (forsoning) betyr å føre sammen igjen. Det er nettopp det Marie skriver om. Mor og datter føres sammen igjen, men ikke på en slik måte at det oppstår harmoni i relasjonen. Marie oppdager de grensene hun selv har satt, og lar dem fare. Mor var i liten grad en del av sin datters liv, men til tross for dette føres Marie sammen med mor ved å overskride de murene hun selv hadde satt opp. Samtidig som Marie arbeider med å forstå og å holde fast ved det som skjer, nærmer døden seg, og hun må gi slipp. For Marie handler det om å gi slipp på egne forsvarsverk, men også om å gi slipp på mor, som hun var kommet tett på i siste fase av livet. 


\section{RELEVANS FOR SYKEPLEIERE}

Hvilken relevans har Maries fortelling for sykepleie? Kan sykepleiere gjøre noe fra eller til i en forsoningsprosess mellom mor og datter? Med stor sannsynlighet vil en sykepleier møte mor og datter, for eksempel i sykehjem som pårørende og pasient. Det å få livstruende diagnoser er smertelig på ulike måter for pasienter og pårørende. Smertelige situasjoner kan gi rom for gode samtaler om relasjoner og tilgivelse. Derfor kan tiden være viktig både for den som skal dø, men også for de pårørende (6). Å være seg dette bevisst kan utgjøre en forskjell i sykepleieres tilnærminger til pårørende.

\section{«Bokens anklagende tittel "Du tror du vet alt" kan også ramme sykepleiere som på forhånd mener å vite hvordan pårørende har det.»}

Mangelfull kjennskap til andres eksistensielle erfaringer gjør det lett å ty til klisjeer i samtaler (7). Bokens anklagende tittel Du tror du vet alt kan også ramme sykepleiere som på forhånd mener å vite hvordan pårørende har det. Motsatt kan kjennskap til andres uro og krevende livssituasjoner være et godt utgangspunkt for gode samtaler, dersom pårørende ønsker det. Ved å være aktivt lyttende og respondere på innspill kan pårørendes møte med sykepleiere føles styrkende (8).

En åpen og sensitiv holdning er det beste utgangspunktet for å kunne innta den andres perspektiv. Det er ikke sikkert at pårørende ønsker å snakke med sykepleiere om eksistensielle spørsmål. Uansett vil de ha behov for å bli møtt med respekt og forståelse for at livet kan smerte. Det er av stor betydning at sykepleiere er oppmerksomme på den andres smerte. I Maries situasjon bærer både datter og mor på smerte, hver for seg og forskjellig fra hverandre.

\section{METODEREFLEKSJONER}

Essay er brukt som kritisk utforskende metode $(9,10)$. Ontologisk innebærer metoden å ta utgangspunkt i menneskers erfaringer som grunnlag for kunnskapsutvikling. Epistemologisk anvendes kritiske spørsmål til erfaringen (teksten) for å fremme refleksjoner og oppdage erfaringenes iboende betydning (9). Metoden blir kritisk og utforskende når spørsmålene resulterer i at egen forutforståelse settes på spill, og nye innsikter kan framtre (10). Det er Maries erfaringer med å være datter til en alvorlig syk mor som granskes.

Michel de Montaigne regnes som essayets opphavsmann. For ham betød «essay» å prøve eller teste (11). Skjønnlitterære tekster kan være fruktbare kilder til å prøve ut egne forståelser faglig og moralsk og på den måten utvikle innsikter i det menneskelige mangfoldet. I denne artikkelen prøves resonnementer ut ved essayistiske refleksjoner over Maries erfaringer.

\section{METODENS GRUNNELEMENT: Å STILLE SPøRSMÅL}

Gadamer (12) hevder at det å stille spørsmål spiller en viktig rolle ved å lære av erfaringer. Spørsmålets vesen er å frisette muligheter og prøve ut disse (12). Hensikten min med å stille kritiske spørsmål til bokens tekster er å kaste lys over datterens erfaringer når mor «går i stykker». I essayet har jeg forsøkt å forstå erfaringene på måter som kan ha relevans for sykepleie. Maries fortelling er unik i den forstand at den er basert på hennes personlige erfaringer. Likevel kan hennes erfaring representere det mange opplever i liknende situasjoner. Det å samle kunnskap og forståelse fra en erfaring representerer en analogisk form for resonnement som kan være overførbart og dermed bidra til betydelig læring (13).

\section{ANALYSEN}


Den systematiske unders $\varnothing$ kelsen av bokens tekst har foregått i tre trinn (9). I det første trinnet leste jeg boken sammenhengende for å få en oversikt. I neste omgang stilte jeg spørsmål til teksten, avsnitt for avsnitt, side for side, kapittel for kapittel. Denne fasen brakte fram meningsenheter med relevans til erfaringene med å være datter når mors kognitive evne svekkes. Jeg navnga meningsenheter med kategorier og temaer, som i arbeidet med å forstå Maries erfaringer brakte fram tre hovedtemaer:

- Det oppstår en trang til å forstå.

- Forståelsen foregår på forskjellige nivåer.

- Å makte å gi slipp når døden ubønnhørlig inntreffer.

I det tredje trinnet unders $\varnothing$ ker jeg fenomenene i en teoretisk refleksjon (9). Her blir temaene belyst med teori. Særlig Arendts (3) beskrivelse av «handling» og «tilgivelse» blir fruktbar for få innsikt i hva Marie slet med i prosessen med å gi slipp og ta farvel med mor.

\section{GYLDIGHET}

Hensikten med refleksjonene er å fange hva Maries erfaringer kan vise, og hvordan det kan åpne for forskningsspørsmål (10) som har betydning for kunnskapsutvikling i sykepleie. Det avgjørende for gyldigheten av de nye innsiktene er hvorvidt lesere kjenner igjen fenomener som beskrives, og hvorvidt de oppfattes som relevante for sykepleiepraksis.

\section{FORSKERROLLEN}

Å skrive om andres erfaringer kan være krevende fordi disse erfaringene alltid vil forstås på bakgrunn av egen forforståelse. Hermeneutikk og fortolkning innebærer at mennesker står bundet i en tradisjon som alltid vil farge nye erkjennelser (12). Utfordringen $\mathrm{i}$ alt fortolkningsarbeid er derfor å være seg bevisst på sitt eget ståsted. Leseren avgjør hvorvidt refleksjonene her skaper gjenkjennelse som kan tjene som en rettesnor for sykepleiere og helsepersonell i praksis.

\section{AVSLUTTENDE REFLEKSJONER OG KONKLUSJON}

Når en nærstående rammes av sykdom, vekkes trangen til å forstå hva som er i ferd med å skje. Det er mye å undre seg over i og med sykdomsutviklingen, og enda mer når døden nærmer seg. Det synes paradoksalt at Marie prøver å «finne fram til sin mor», uten noen gang å nå fram. Men hun finner ro og forsoning i at de prøvde.

Forståelse foregår på ulike nivåer. Samtidig med at hun bruker krefter på å begripe det som skjer, nærmer døden seg. Paradoksalt nok skal Marie gi slipp samtidig som hun søker å forstå. Hvilken hjelp er det mulig å gi en pårørende som strever med å forstå og holde fast, og på samme tid skal gi slipp?

Boken viser innlevende det relasjonelle samspillet mellom en syk mor og hennes datter fram mot morens $\mathrm{d} \emptyset \mathrm{d}$. Datterens deltakelse i morens lidelser og hennes strev med å gjenfinne fotfeste gjør oss klokere, og vi forstår hva som står på spill i relasjonen. Slik er boken en unik kilde til å forstå både mor og datter. Den inspirerer til samtaler om relasjoner, livet og døden - og behovet for sykepleiefaglig støtte.

Takk til professor Ingela Josefson for lesninger av manus og verdifulle samtaler i arbeidet med artikkelen. Takk også til Senter for praktisk kunnskap, Nord universitet, for inspirasjon gjennom lærerike diskusjoner.

\section{REFERANSER}

1. Peterson M. Du tror du vet alt. Ganesa, Oslo. 2007.

2. Sjöstrand L. Den fragmenterade tiden. Dialoger 85-86. Dialoger, Sverige. 2008. 
3. Arendt H. Vita activa. Pax Forlag, Oslo. 1996.

4. Quenstedt-Moe GW. Forgiveness and health in Christian women. (Doktoravhandling). University of Kansas. 2007.

5. Knowles A. Resilience among Japanese atomic bomb survivors. Int Nurs Rev. 2011;58(1):54-60.

6. Prince-Paul M, Exline JJ. Personal relationships and communication messages at the end of life. Nurs Clin North Am. 2010;45(3):449-63.

7. Kautz D. Inspiring hope in our rehabilitation patients, their families, and ourselves. Rehabil Nurs. 2008;33(4):148-77.

8. Mickley JR, Cowles K. Ameliorating the tension: use of forgiveness for healing. Oncol Nurs Forum. 2001;28(1):31-7.

9. Lindseth A, Norberg A. A phenomenological hermeneutical method for researching lived experience. Scand J Caring Sci. 2004;18:145-53.

10. McGuirk J, Methi JS. Praktisk kunnskap som fag og forskningsfelt. I: McGuirk J, Methi JS (red). Praktisk kunnskap som profesjonsforskning. Fagbokforlaget, Bergen. 2015. s. 9-30.

11. Melberg A. Essayet. Universitetsforlaget, Oslo. 2013.

12. Gadamer HG. Sannhet og metode. Pax Forlag, Oslo. 1960.

13. Flyvbjerg B. Case study. I: Norman KD, Lincoln YS (red). The SAGE Handbook of Qualitative Research. Sage Publications, Los Angeles. 2011. 